\title{
REVISTAMARACANAN
}

Dossiê

\section{Romantismo Nos Trópicos: Motivos Literários No Brasil Oitocentista}

\author{
Romanticism In The Tropics: Literary Motives In Brazil Of The Ninetenth \\ Century)
}

\author{
Antônio Sérgio Pontes Aguiar \\ PUC-Rio \\ sergioaguiar.hist@gmail.com
}

Ruben Maciel Franklin

Universidade da Integração Internacional da Lusofonia Afro-brasileira

rbnhist@yahoo.com.br

\begin{abstract}
Resumo: Este artigo tem como objetivo discutir a emergência do romantismo no Brasil a partir dos debates promovidos pelos romancistas e críticos no decorrer do século XIX, atentando para como seus protagonistas estavam inseridos na vida política local e como, a partir daí, forjaram um movimento de traços nacionais. Para isto, analisamos algumas das principais obras lançadas à época, bem como nos atemos a uma revisão bibliográfica sobre o tema em questão. Observamos que o romantismo, enquanto movimento literário e artístico, também trouxe à tona uma série de problemas concernentes aos temas centrais que pautariam uma literatura tipicamente nativa, a relação dos (escritores) brasileiros com a cultura europeia e a própria luta pela afirmação de uma identidade nacional num contexto de reorganização política e busca pelos valores que sustentariam a Nação recém-independente (1822).
\end{abstract}

Palavras-chave: Romantismo. Literatura. Brasil. Nação.

Abstract: This article aims to discuss the rise of romanticism in Brazil from the debates raised by novelists and critics during the nineteenth century. For this, we analyze some of the major works launched at the time, as well as we turn to a literature review on the topic. We note that Romanticism, as a literary and artistic movement, also brought to light a number of issues concerning the core themes that would create a typical native literature, the relationship of Brazilians (writers) with European culture and the very struggle for the affirmation of a national identity in a context of political reorganization and search for the values that could sustain the newly independent nation (1822).

Keywords: Romanticism. Literature. Brazil. Nation. 
Sobretudo compreendem os críticos a missão dos poetas, escritores e artistas, nesse período especial e ambíguo da formação de uma nacionalidade. São estes os operários incumbidos de polir o talhe e as feições da individualidade que se vai esboçando no viver do povo.

(José de Alencar)

romantismo encontrou no Brasil sua "oportunidade histórica", como bem observou Antonio Candido. Coincidindo e se ajustando ao espírito da nação ainda por formar-se, foi reapropriado de forma original de acordo com as particularidades locais, sem perder seu elo com a matriz europeia. Era 1822 quando o Estado brasileiro se emancipou sem uma base de referência vigorosa para fazer dos habitantes desse imenso território autênticos "brasileiros".

É devido ao caráter próprio do romantismo, particularista, relativista, enfático em apreender as singularidades de um povo, de uma nação, de um espírito específico, que podemos entender como se configurou e desenvolveu o pensamento romântico no Brasil. Um país desprovido de transformações sociais mais profundas do modo como ocorria na Europa, as quais propiciaram o surgimento da cultura romântica no Velho Mundo. ${ }^{1}$

Porém, deve-se ter cuidado ao falar de romantismo em terras brasílicas para não sermos levados a uma identificação integral com o pensamento europeu, "de que constitui ramificação cheia de peculiaridades". 2 Aqui, bem como nos demais países recémindependentes, a fecundidade do romantismo se deu na medida em que se aliou ao nacionalismo, onde o escritor cultivaria um senso de dever patriótico a partir da inserção da literatura num projeto construtivo mais amplo, como instrumento de edificação e engrandecimento da nação. Alcançada a independência política, tornava-se urgente sua consolidação por meio da criação de elementos peculiares e distintivos do Brasil e, por conseguinte, pelo cultivo de um sentimento de fidelidade e serviço à pátria. O sentido de missão dá o tom para os literatos românticos. Se na literatura colonial os escritores voltaramse, sobretudo, para as belezas naturais do país, durante o período romântico há um forte interesse tanto para as características do país como, especialmente, do brasileiro, como povo e indivíduo.

Nesse sentido, a criação e a difusão da ideia de nação no Brasil, enquanto persuasão dos "brasileiros" como pertencentes a uma pátria, foi obra do pensamento romântico. ${ }^{3}$ É no seio de uma jovem nação, incerta quanto ao seu futuro e o modo de construí-lo, que o romantismo encontraria terreno fértil para suas ideias. Seus temas e a maneira como tratou os mesmos, ajustados à necessidade de demarcar as peculiaridades originais de um território e seu povo, pareciam servir ao propósito de criar um espírito nacional a partir da reunião do que seria o "povo brasileiro". Desse modo, os símbolos românticos (figuras, ideias, imagens)

\footnotetext{
${ }^{1}$ COUTINHO, Afrânio. Conceito de Literatura Brasileira. Rio de Janeiro: Pallas; M.E.C., 1976.

2 CANDIDO, Antonio. Formação da Literatura Brasileira. Rio de Janeiro: Ouro Sobre Azul, 2007.

3 RICUPERO, Bernardo. O romantismo e a ideia de nação no Brasil (1830-1870). SP: Martins Fontes, 2004.
} 
basilares criados pela literatura nacionalista, que a constituía em sua diferença, seriam o índio, ${ }^{4}$ a natureza brasileira e a linguagem.

O modo como a cultura romântica pensou a nação no Brasil parece encontrar correspondências com a famosa conferência de Renan, onde, após levantar alguns dos fatos que seriam erroneamente associados à conquista de um "direito nacional" (raça, língua, religião, comunhão de interesses), o historiador francês arremata:

A nação é uma alma, um princípio espiritual. (...) a posse em comum de um rico legado de lembranças; o consentimento atual, o desejo de viver juntos, a vontade de continuar a fazer valer a herança que recebemos indivisa. A nação, como o indivíduo, é o resultado de um longo passado de esforços, de sacrifícios e devoções. ${ }^{5}$

Não obstante o impasse da crítica em enxergar nesse período a "formação" ou a "autonomia" da literatura brasileira, o momento não deixa de ser "decisivo". 6 Dotados de um agudo senso de dever patriótico, os escritores utilizaram deliberadamente a literatura como arma poderosa na consolidação de nossa independência, uma vez que apenas a emancipação política e a construção da máquina estatal não seriam suficientes para compor uma nação plena e garantir seu lugar no concerto das nações cultas. A novidade da geração romântica estaria nessa atribuição de sentido patriótico à literatura, uma finalidade que a ultrapassa.

Para Antonio Candido,

Um elemento importante nos anos de 1820 e 1830 foi o desejo de autonomia literária, tornado mais vivo depois da Independência. Então o Romantismo apareceu aos poucos como caminho favorável à expressão própria da nação recém-fundada, pois fornecia concepções e modelos que permitiam afirmar o particularismo, e, portanto, a identidade, em oposição à Metrópole, identificada com a tradição clássica. Assim surgiu algo novo: a noção de que no Brasil havia uma produção literária com características próprias, que agora seria definida e descrita como justificativa de reivindicação de autonomia espiritual. ${ }^{7}$

\footnotetext{
${ }^{4} \mathrm{O}$ interesse que os escritores românticos nutriram pela natureza americana e os aborígenes foi despertado pela obra de Chateaubriand, que Ihes revelou uma matéria literária que eles tinham em sua própria terra. Leyla Perrone-Moisés (PERRONE-MOISÉS, Leyla. Vira e mexe nacionalismo. Paradoxos do nacionalismo literário. SP: Cia das Letras, 2007, p. 38) diz que: "Os índios constituíam uma matéria romanesca e poética com múltiplas vantagens: eram aquela origem mítica necessária a toda nação; eram nossa parte original, não-europeia; já quase exterminados, prestavam-se a todas as fantasias; serviam de biombo para os negros, que estavam demasiado próximos e suscitavam a questão espinhosa da escravidão, cuja abolição só se tornou tema literário quando iminente, por consenso e pressão internacional".

5 RENAN, Ernest. O que é uma nação? In: ROUNET, Maria Helena (Org.). Nacionalidade me questão. Caderno da Pós/Letras 19. Rio de Janeiro: Uerj, 1997, p. 39.

6 Afrânio Coutinho (1968, 1976a), em crítica dirigida a Antonio Candido, afirmou que a literatura brasileira "formou-se" com o Barroco, a despeito de não ser ainda uma literatura orgânica funcionando como um sistema coerente. Com o arcadismo-romantismo, ela teria alcançado sua autonomia. Com o modernismo, atingiu sua maioridade.

7 CANDIDO, Antonio. O romantismo no Brasil. São Paulo: Humanitas, 2004, p. 19.
} 
Segundo Abel Baptista, os românticos brasileiros viveram a ilusão de dois começos: o do Brasil como nação independente, e da literatura enquanto independente e deveras nacional. O romantismo brasileiro ia além de um programa de nacionalização literária, pois teve o mérito histórico de fundar a literatura brasileira como projeto moderno. A inserção do Brasil na modernidade se deu pela via das letras e dos debates intelectuais do período, os quais, aliando as leituras de autores estrangeiros e os enfrentamentos ante a condição de país recémindependente, promoveram uma profícua circulação de ideias e teorias que não cabiam em formulações sociológicas do tipo "ideias fora do lugar" ou que pensasse a realidade nacional por aquilo que Ihe faltava. O Brasil do século XIX produziu ideias.

Desde modo, os românticos brasileiros viveram o seu romantismo em acordo com o presente (...) fundar uma literatura nacional brasileira implicava cortar com o passado, clássico e colonial ao mesmo tempo, ou seja, a novidade, a originalidade e a invenção, lugares-comum da nossa época. ${ }^{8}$

Após 1822, dever-se-ia optar por um modelo que se desviasse do colonial, luso e ibérico que havia sido imposto pela metrópole e que impedia a formação de uma nação autônoma e moderna. Se, para Afrânio Coutinho - crítico de Antonio Candido e seu conceito histórico-sociológico de literatura como "fenômeno de civilização" -, o Barroco no Brasil teve um caráter essencialmente nativista como reação ao quinhentismo e ao espírito renascentista português, para Antonio Candido essa reação se deu pela primeira vez apenas com o Arcadismo e o Romantismo, este último voltado quase que inteiramente para a França.

Se do ponto de vista econômico a Inglaterra é quem tem a primazia sobre o consumo brasileiro, em geral, do ponto de vista artístico-literário, pouco se conhecesse sobre os ingleses e é da França que nos chegam os novos romances e folhetins a serem consumidos. ${ }^{9}$

A difusão da França como referência cultural para a jovem nação se iniciaria antes mesmo do processo de Independência política, quando D. João VI providenciara a vinda da Missão Artística Francesa, em 1816, e a fundação de uma Escola de Belas-Artes de moldes franceses com o intuito de civilizar a nova capital do reino, dotando-a de significativas inovações arquitetônicas, urbanísticas e artísticas. Mas como nos expressar de forma autônoma e original se o fazemos na língua do opressor português? Como evitar o dano de produzir para "opulentar o tesouro da metrópole"? Quais temas deveriam permear a literatura brasileira que se inaugurava?

A resposta a essas antinomias viria justamente de um francês, fundador da teoria e da nossa historiografia literária: Ferdinand Denis. Jovem e fascinado pela realidade brasileira (sua

8 BAPTISTA, Abel Barros. A formação do nome. Duas interrogações sobre Machado de Assis. Campinas: Ed. Unicamp, 2003, p. 28.

9 BAREL, Ana Beatriz Demarchi. Um romantismo a oeste. Modelo francês, identidade nacional. SP: AnnaBlume, 2002, p. 24 e 25. 
natureza exuberante, seus costumes estranhos, a rudeza do clima, a cidade, o campo), o estrangeiro formulou, quatro anos após a Independência, o problema que acompanharia os intelectuais brasileiros durante os anos posteriores: a necessária, e não menos importante, "independência literária"10 da nação. Em seu Resumo da História Literária do Brasil (1826), Denis formulou as diretrizes para uma literatura autônoma e original:

Se os poetas dessas regiões fitarem a natureza, se se penetrarem da grandeza que ela oferece, dentro de poucos anos serão iguais a nós, talvez nossos mestres. Essa natureza muito favorável ao desenvolvimento do gênio, esparze por toda parte seus encantos, circunda os centros urbanos com os mais belos dons; e não é como em nossas cidades, onde a desconhecem, onde muitas vezes não a percebem (...). ${ }^{11}$

E ainda em relação ao papel da França:

Mas, fato verdadeiramente notável é a influência que nossa literatura exerce hoje em dia sobre a dos brasileiros. Orgulham-se estes dos autores que fixaram a sua língua; mas leem os poetas franceses, conhecendo-os a quase todos. O papel que nos cabe desempenhar nesse país é ainda muito significativo. ${ }^{12}$

Denis se baseia no princípio moderno de que um país que detém uma fisionomia geográfica, étnica, social e histórica definida deveria ter sua literatura particular, que o expressasse, pois esta era estritamente relacionada com a natureza e a sociedade de cada lugar. Desse modo, os costumes, a natureza e o indígena (autêntico habitante do continente americano) foram temas de grande inspiração poética a serem descritos, produzindo assim uma literatura nacional. Em sua interpretação da vida literária nativa, o viajante estrangeiro observou que a literatura brasileira nascera no século XVIII, estendendo sua análise sobre os árcades mineiros como Basílio da Gama e Santa Rita Durão, cuja obra vinculada ao tema indianista servira de arquétipo para os que estavam fazendo literatura em sua época.

Além de Denis, Almeida Garret, introdutor do romantismo em Portugal, também insistiu na necessidade que o Brasil teria de uma literatura autônoma, verificando em tom pesaroso que a educação europeia tivesse apagado o espírito nacional nos poetas brasileiros.

Outro estrangeiro que contribuiu no lançamento das bases de nossa história literária foi Ferdinand Woolf. Com seu Brasil literário. História da Literatura Brasileira, publicado em 1862 sob o patrocínio de D. Pedro II, Woolf retomou alguns posicionamentos de Denis no que se refere à influência mesológica sobre a literatura e deu destaque ao papel da natureza para a

10 O campo de ação por excelência é a própria literatura, que, diferentemente da história, não deveria sofrer a ação das modificações geradas pela inapelável marcha da civilização (marcas do europeu), mas sim registrar a permanência dos valores primordiais, marcas originais da terra americana. Ver também: ROUNET, Maria Helena (org.). Nacionalidade me questão. Caderno da Pós/Letras 19. RJ: Uerj, 1997.

${ }^{11}$ DENIS, Ferdinand. Resumo da História Literária do Brasil. In: CESAR, Guilhermino (org.). Historiadores e críticos do romantismo. 1. A contribuição europeia: crítica e história literária. SP/RJ: Edusp/LTC, 1978, p. 37 e 38.

12 Id. Ibidem, p. 41. 
autonomia literária da nação, não meramente enquanto tema (como aparece no Resumé de Denis), mas também como fator determinante das formas de expressão. A literatura foi trazida ao Brasil pelo colonizador. Desprovidos de cultura literária, os indígenas só poderiam intervir de forma indireta na literatura, a partir do cruzamento com os portugueses, formando, após dois séculos, o caráter brasileiro e sua literatura.

Primeira visão orgânica da literatura nacional, seu texto demarca os sucessivos períodos pelos quais passou a literatura no Brasil até aquele momento (1840-1862). Inicia com os jesuítas e colonos portugueses imitadores dos modelos português e espanhol; se expande no século XVIII com a fundação de sociedades literárias, persistindo a imitação; ao fim do século desponta a escola de Minas Gerais como principal representante desse movimento; adquire caráter nacional, no século XIX, com os românticos sob a influência direta das literaturas francesa e inglesa. E conclui:

Por imperfeito que seja este ensaio, o leitor poderá tirar daí, com certeza, os resultados seguintes: A literatura brasileira pode pretender, a justo título, que a consideremos verdadeiramente nacional; por esta qualidade, tem um lugar marcado no conjunto das literaturas do mundo civilizado; enfim, notadamente no último período, desenvolveu-se em todas as direções e produziu nos principais gêneros obras dignas da atenção de todos os amigos das letras. ${ }^{13}$

Mas é num texto de 1843, escrito por Santiago Nunes Ribeiro, que a crítica alcança maturidade e lucidez. Da nacionalidade da literatura brasileira, publicado na revista Minerva Brasiliense, desenvolve as ideias correntes e afirma a autonomia da literatura brasileira desde as origens. Para ele, a poesia brasileira da época anterior à independência foi o que deveria ser: "Porventura poderia ela ser a expressão das ideias e sentimentos de outros tempos"? Aqui, não há motivos para se lamentar, no passado, a sujeição dos árcades às normas clássicas, uma vez que consistia na orientação estética padrão de seu tempo. Priorizando a correlação entra a obra e sua época, a crítica romântica não deveria ser dogmática, presa a modelos rígidos. Desse modo, segundo Candido "[Santiago Nunes Ribeiro] não apenas avaliou com maior pertinência a produção literária no Brasil, mas estabeleceu a primeira divisão satisfatória de suas etapas". ${ }^{14}$

Entre os anos que separam o texto de Denis e o marco inicial do romantismo brasileiro, em 1836, tais ideias programáticas seriam amadurecidas pelos intelectuais do período, tais como a consciência de autonomia, a busca de um passado literário e o destaque para temas nativistas. Em suma, o pendor para a cultura romântica que, àquele momento, ainda não havia sido assim nomeada.

\footnotetext{
${ }^{13}$ WOLF, Ferdinand. O Brasil Literário. História da Literatura Brasileira. In: CESAR, Guilhermino (org.). Historiadores e críticos do romantismo. 1. A contribuição europeia: crítica e história literária. SP/RJ: Edusp/LTC, [1863], 1978, p. 180.

${ }^{14}$ CANDIDO, Antonio. O romantismo no Brasil. São Paulo: Humanitas, 2004, p. 36.
} 
Em 1829, portanto três anos após o texto de Denis, Januário da Cunha Barbosa escreveu o Parnaso Brasileiro, a primeira antologia da literatura brasileira, composta somente pelos poetas nativos. Em sua nota de abertura, Ao Público, Januário afirmou que seu intuito era:

(...) tornar ainda mais conhecido no mundo literário o gênio daqueles brasileiros, que, ou podem servir de modelos, ou de estímulo à nossa briosa mocidade, que já começa a trilhar a estrada das belas letras, quase abandonada nos últimos vinte anos dos nossos acontecimentos políticos. ${ }^{15}$

Para ele, a literatura se definia como sendo aquela produzida por brasileiros de nascimento. Não obstante o debate em torno da necessidade ou existência de uma literatura nacional separada e diferente da portuguesa esteja ausente. Na sua origem e formação, esse seria um problema posto somente pelos românticos, buscando delimitar os caracteres e as condições que autonomizaram a literatura brasileira, e o momento em que esse processo ocorreu. Seu objetivo era, entretanto, reunir as melhores poesias de poetas brasileiros, a fim de que as mesmas pudessem ser divulgadas no mundo literário e servissem até mesmo de modelo e estímulo aos que davam os primeiros passos nas belas-letras da jovem nação. Para que estes se aperfeiçoassem, a partir do exemplo modelar dos poetas maiores,

Não era necessária uma história da literatura. A única operação histórica requerida era o estabelecimento de uma fronteira entre um momento passado de desordens e a nova ordem presente que se abria. O "Parnaso Brasileiro" é, por isso, uma coleção de exemplos, e não uma narrativa histórica do desenvolvimento de uma literatura. ${ }^{16}$

Entre os vários elementos que uma nação civilizada deveria possuir, a literatura nacional tem seu lugar assegurado. As letras poderiam contribuir, também, para um clima ameno, neutralizando as animosidades e adoçando costumes, necessários a uma nação civilizada. Segundo Valdei Lopes de Araújo, ao demarcar enfaticamente um "agora", frente a um passado próximo de lutas e conflitos ("Agora, porém, que o Brasil, felizmente desassombrado da opressão antiga..."), Januário demonstrava o desejo de se afastar de um momento instável que tardava em desaparecer. Pouco tempo depois, D. Pedro I seria afastado do poder, iniciando o período conturbado da Regência, frustrando, assim, a empresa de Januário em iniciar um período pacífico favorável às letras. É nesse momento que Magalhães termina seu ensaio em tom pesaroso, mas entusiasmado:

\footnotetext{
15 BARBOSA, Januário da Cunha. Ao Público. In: ZILBERMAN, Regina; MOREIRA, Maria Eunice. O Berço do Cânone: textos fundadores da história da literatura brasileira. Porto Alegre: Mercado Aberto, 1998, p. 84.

16 ARAUJO, Valdei Lopes de. A experiência do tempo. Conceitos e narrativas na formação nacional brasileira (1813-1845). SP: Hucitec, 2008, p. 111 e 112.
} 
Tu vais, oh livro, ao meio do turbilhão em que se debate nossa Pátria; onde a trombeta da mediocridade abala todos os ossos, e desperta todas as ambições; onde tudo está gelado, exceto o egoísmo: tu vai como uma folha no meio da floresta batida pelos ventos do inverno, e talvez tenhas de perder-te antes de ser ouvido, como um grito no meio da tempestade.

É no Velho Mundo (na França), em 1836, nosso "manifesto romântico", protagonizado pelos jovens brasileiros Gonçalves de Magalhães, Torres Homem e Araújo Porto Alegre, membros de nossa diplomacia cultural na Europa. Bem acolhidos em Paris por Ferdinand Denis e Monglave, lançaram a revista Niterói, com o subtítulo Sciencias, Lettras e Artes. Tudo pelo e para o Brasil. Trazendo no título uma palavra indígena, o periódico já dava os primeiros sinais de um programa nativista. De caráter eclético e multitemático (artes, literatura, ciência, filosofia, música astronomia, economia, física, química), denotando ausência de especialização, a revista, em seus dois únicos números, se apresentou como vigoroso instrumento de afirmação nacional, consolidando o papel da França enquanto referência primordial para a nossa vida espiritual. Além disso, seus idealizadores apresentavam um claro interesse em demarcar seu público ledor, como bem assinalou Ana Beatriz D. Barel:

A intenção dos autores de Niterói é a de atingir o dito "leitor comum", o homem ordinário, do povo, diferenciando-o do especialista, do intelectual, "dos homens exclusivos, que de todo se dedicam às ciências" (...). Nada mais romântico, por outro lado, que aliar nacionalismo e apelo popular, ecletismo e erudição numa publicação que se queria representativa de uma identidade em formação e em sintonia com os valores da vanguarda cultural internacional, então liderada pela França. ${ }^{17}$

Porém, tal público não passaria de uma entidade ficcional, visto a pouca difusão do idioma português na Europa e o desconhecimento de nossa literatura, bem como da portuguesa, pelos demais países, o que possivelmente contribuiu para a efemeridade da revista.

É no primeiro tomo de Niterói que encontramos o texto oficial que inaugurou o romantismo brasileiro: Ensaio sobre a história da literatura do Brasil - estudo preliminar de Gonçalves de Magalhães, que, junto com o prefácio de Suspiros poéticos e saudades (1836), viria a fundar a nova sensibilidade. Em relação ao passado colonial, Magalhães é enfático:

O Brasil, descoberto em 1500, jazeu três séculos esmagado debaixo da cadeira de ferro, em que se recostava um Governador colonial com todo o peso de sua insuficiência, e de seu orgulho (...). Para o brasileiro, no seu país, obstruídas e fechadas estavam todas as portas e estradas que podiam conduzi-lo à ilustração.

17 BAREL, Ana Beatriz Demarchi. Um romantismo a oeste. Modelo francês, identidade nacional. SP: AnnaBlume, 2002, p. 38. 
Uma só porta ante seus passos se abria; era a porta do convento, do retiro, e do esquecimento.

Mas no passado literário também havia exemplos válidos para o desenvolvimento e avanço dos temas nacionais. Santa Rita Durão e Basílio da Gama, lembrados por Denis como modelos, também constarão nos escritos dos jovens da Niterói, com seus poemas pincelados de "cor local" e trato indianista. Figuras tão diferentes quanto Porto Alegre, Santiago Nunes, Álvares de Azevedo e José de Alencar manifestaram-se favoravelmente às obras dos árcades mineiros como encarnação do espírito nacional e particularista, "que os românticos desejavam a todo custo vislumbrar no passado, a fim de sentir a presença de uma tradição que apoiasse e desse foros à sua tomada de consciência." 18 Nesse sentido, um poema como Caramuru (1781) desempenhará um importante papel na demonstração de uma continuidade das manifestações dos traços peculiares nacionais, do meio e do homem, na vida espiritual.

Enunciando a adoção de uma nova estética política e cultural, Magalhães ${ }^{19}$ não tardou em reforçar a filiação brasileira ao modelo francês, dizendo que "hoje o Brasil é filho da civilização francesa, e como Nação é filho dessa revolução famosa que abalou todos os tronos da Europa, e repartiu com os homens a púrpura e os cetros dos reis".

E foi da França que Magalhães herdou a filosofia eclética, pela qual ficou deslumbrado e que, com sua proposta de conciliação de todos os sistemas, podia atender às exigências de apaziguamento de um período sociopolítico instável como a Regência. Segundo Cruz Costa, a filosofia eclética no Brasil estava vinculada ao momento de estabilidade que se seguiu ao advento e consolidação do regime monárquico de D. Pedro II, nos decênios 1840-1850. ${ }^{20}$

Ao longo de seu ensaio, Magalhães apresenta suas diretrizes românticas, quais sejam: a recusa da imitação dos textos clássicos em prol da natureza, dando vazão à originalidade do gênio criador - "Quanto a nós, a nossa convicção é que - nas obras do gênio o único guia é o gênio; que mais vale um voo arrojado deste, que a marcha refletida e regular da servil imitação" -; a adoção do verso livre e sem moldes pré-concebidos para a composição poética, dando liberdade ao discurso e ao sentimento, - "Convém, é certo, estudar os antigos e os modelos dos que se avantajaram nas diversas composições poéticas, mas não escravizar-se pela cega imitação" -; o sentimento religioso que atribui à poesia uma função moral, - "O poeta sem religião, e sem moral, é como o veneno derramado na fonte, onde morrem quantos aí procuram aplacar a sede". Magalhães professava ainda sua crença nos valores da civilização moderna e no progresso, engendrados pela Revolução Francesa e sua tarefa de esclarecimento dos povos. Nesses moldes, segundo Barel, "A Niterói assume, como se pode verificar, um

\footnotetext{
18 CANDIDO, Antonio. O romantismo no Brasil. São Paulo: Humanitas, 2004, p. 191.

19 MAGALHÃ̃ES, Gonçalves de. Discurso sobre a História da Literatura do Brasil In: (org.). Caminhos do pensamento crítico. Vol 1. RJ: Pallas, 1980, p. 33.

20 CRUZ COSTA, João. Contribuição à história da ideias no Brasil. RJ: Civilização Brasileira, 1967.
} 
papel de divulgação de ideias da nova escola, uma reivindicação de literatura nacional, mas, acima de tudo, uma explicitação da hegemonia cultural francesa nas letras brasileiras". ${ }^{21}$

Essa parece ter sido sua principal contribuição: não a fundação do movimento romântico no Brasil, nem o oferecimento de um manifesto romântico que instituísse o novo padrão estético no país, mas o esforço em germinar uma identidade cultural nacional única e original, pressuposto para uma nação moderna no século XVIII.

Tendo em vista essas questões, Barel, a quem seguimos aqui, chega a lançar até mesmo a hipótese de que Niterói desempenhasse mais uma função diplomático-documental, sem grandes intenções literário-artístico-científicas, como possa parecer a um olhar mais descuidado.

Destarte, esse romantismo inicial foi antes de tudo programático, convivendo em harmonia com a tradição. Seus mentores ainda escreviam tragédias nos moldes clássicos e epopeias. Em A Confederação dos Tamoios, poema de dez cantos publicado em 1856, Magalhães narrou uma rebelião de índios contra o colonizador no século XVI. ${ }^{22}$ Após sete anos de preparo (foi encomendado pelo Imperador a fim de promover uma história da nova nação), com o propósito de se estabelecer como a grande demonstração da legitimidade nacional do tema indianista, o poema foi muito mal recebido pela crítica e se torno o centro de polêmica nos jornais da época, sobretudo, a discussão travada entre o Imperador, que assinava sob o pseudônimo de "Outro amigo do poeta", e José de Alencar, que assinava como "Ig". Alencar atacava a chateza de conceitos de que abusava Magalhães, que tornava sua obra desinteressante e pesada:

O imperador jamais desconfiaria de que a produção da epopeia viesse a gerar um divisor de águas. A polêmica produzida em torno do poema de Magalhães rompeu a unidade da fase ultrarromântica, desfazendo a coesão dos intelectuais em torno do projeto e anunciando outras possibilidades que iam além do controle da Corte. Alencar foi o representante dessa primeira ruptura, porque ele inaugurou a polêmica em torno de "A confederação dos tamoios", dirigindo para si o olhar do imperador, que viria a se intrometer pessoalmente na questão. ${ }^{23}$

21 BAREL, Ana Beatriz Demarchi. Um romantismo a oeste. Modelo francês, identidade nacional. SP: AnnaBlume, 2002, p. 49.

22 Segundo Roque Spencer M. de Barros (1973), Magalhães buscava criar uma literatura nacional como "projeto de vida" brasileira. Antes, tínhamos duas epopeias "clássicas": o Uruguai e Caramuru. Porém, ambas foram criadas num momento não inteiramente nacional da existência brasileira. Agora, faz-se patente o país recém-independente retomar o seu passado (na forma de um símbolo ou episódio contido nele) e lançar uma nova luz. Idealizar as origens com fins de assentar o presente e, especialmente, 0 futuro. Ligada ao mito, a epopeia é o gênero que se presta a essa revalorização do passado que fundamenta a nacionalidade nascente. "Nesse sentido, Magalhães continua romântico ao converter-se em poeta épico: não propriamente pela escolha do gênero, mas pela deliberação nacionalista com que o faz, pela busca da singularidade nacional que se delineia entre os habitantes primitivos do País e por uma 'filosofia poética da história' pela qual se justifique a incorporação desse passado ao presente, pela mediação necessária da civilização europeia".

${ }^{23}$ RODRIGUES, A. E. M. José de Alencar: o poeta armado do século XIX. Rio de Janeiro: FGV, 2001, p. 91. 
Alencar ocupou o centro da crítica literária romântica. Arguto e perspicaz, ele soube aplicar as teorias literárias e estéticas de sua época às análises das obras de seus pares. Não só pela sua obra poética, mas por suas inúmeras críticas presentes em seus prefácios, posfácios e polêmicas, Alencar detém o maior destaque no processo de integração nacional da literatura.

Em sua série de cartas sobre o poema épico de Magalhães, podemos observar a nítida diferença de perspectiva entre este e o escritor cearense no que se refere à compreensão das formas e temas que devem pautar a literatura nacional:

Depois da invocação segue a descrição do Brasil: há nessa
descrição muitas belezas de pensamento, mas a poesia, tenho
medo de dizê-lo, não está na altura do assunto (...) se algum dia
fosse poeta, e quisesse cantar a minha terra e as suas belezas, se
quisesse compor um poema nacional, pediria a Deus que me
fizesse esquecer por um momento as minhas ideias de homem
civilizado. Filho da natureza embrenhar-me-ia por essas matas
seculares (...) Ia-me esquecendo o poema: é natural! A descrição
do Brasil inspira-me mais entusiasmos do que o Brasil da
descrição. O poeta no seu poema descuidou-se inteiramente da
forma, o que aliás é natural, pois o estudo da poesia estrangeira
provavelmente fez-lhe perder o gosto apurado e a suavidade e
cadência do verso português. Há no seu poema um grande abuso
de hiatos, e um desalinho de frase, que muitas vezes ofende a
eufonia e doçura de nossa língua. ${ }^{24}$

A primeira geração romântica, tendo em Gonçalves de Magalhães (ocidentalista) seu principal mentor, preocupou-se com o Estado, aliando literatura e política (afinal, eram homens vinculados ao corpo diplomático brasileiro, deputados, senadores, ministros, e, portanto, vinculados intimamente à máquina estatal) a partir de um modelo que assegurasse a construção da nacionalidade. Mas foi da segunda geração, ${ }^{25}$ com José de Alencar (nacionalista), que veio uma proposta mais rica e original para se pensar o Brasil, não enquanto nação sem vida, produção fria de um modelo cosmopolita e exógeno, como a que vemos em Magalhães e seu poema épico $A$ Confederação dos Tamoios, que visava tão somente legitimar o Estado Imperial. O esforço de Alencar ao "pintar" o Brasil em suas cores locais é feito na medida em que ele experimentou o meio na condição de sujeito sensível, numa atitude que vai de seu âmago subjetivo, do seu sentimento íntimo de romancista e aflora em uma operação estética que ficcionaliza o real para, enfim, apreendê-lo de maneira compreensiva.

\footnotetext{
${ }^{24}$ ALENCAR, José de. Cartas sobre a Confederação de Tamoios. In: COUTINHO, Afrânio (org.). Caminhos do pensamento crítico, vol. 1. RJ: Pallas, 1980, p. 80, 81-83.

25 Tradicionalmente, a historiografia literária estabeleceu diversas fases do romantismo no Brasil. Afrânio Coutinho, em Introdução à literatura brasileira, identifica 4 grupos: 1) Inicia-se com o grupo fluminense e o manifesto contido na revista Niterói $(1836) ; 2$ ) Compreende os anos 1840-1850, onde, sob influência de Chateaubriand, Walter Scott, Balzac, Eugene Sue, Cooper, predominam a descrição da natureza, o panteísmo, a idealização do selvagem, o indianismo; 3) A influência de autores como Byron, Musset e Lamartine, levam os escritores do decênio 1850-1860 a expressarem um individualismo e subjetivismo marcados pela dúvida e desilusão; 4) Após 1860, tem-se um Romantismo liberal e social, envolto nas lutas pelo abolicionismo e pela Guerra do Paraguai.
} 
Em Alencar, não é a nação portentosa que posa para o artista. O romancista está focado na busca da expressão de uma brasilidade, não na nacionalidade. O Brasil não é um "ente" suspenso sobre os sujeitos, mas é experimentação viva. A natureza, longe de ser meramente a fauna e flora que ocupa o espaço físico-geográfico brasileiro, é o sentimento sublime que o sujeito criador experimenta ao agir sobre o meio e receber as respostas deste. Em seu nacionalismo literário, Alencar buscou a diferença particular, não a semelhança que produzia uma unidade artificial. Com sua obra, uma vigorosa cultura romântica se configurou no Brasil a fim de lhe dar uma interpretação condizente com o que havia de mais próprio nele.

Assim, nos dizeres de Antonio Candido:

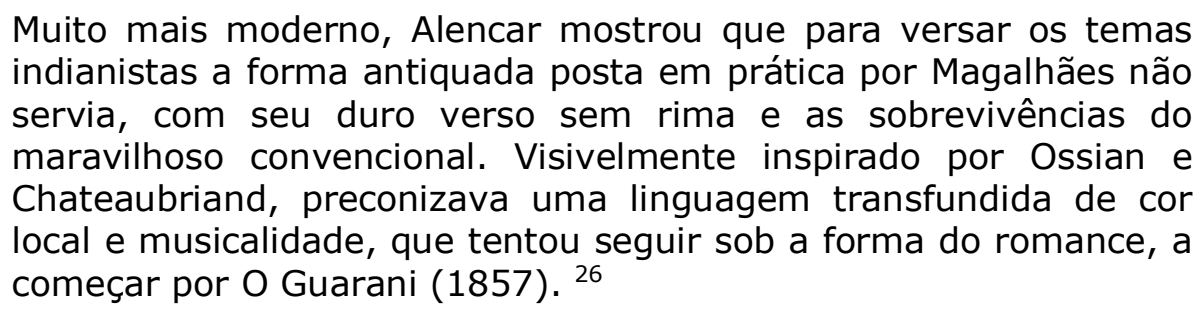

Alencar tentou, assim, elaborar uma história geral da civilização brasileira, escrita através de seus romances. O romancista tinha a pretensão de oferecer uma interpretação do passado que podia muito bem ser mais verdadeira que os relatos dos cronistas e dos historiadores, dos quais por vezes discordava. Segundo Régis Lopes Ramos, em artigo onde compara as versões para a história do Ceará entre os primos José de Alencar e Tristão de Alencar Araripe,

As notas de Iracema não são, portanto, simplesmente coisas
secundárias, pois funcionam em uma lógica argumentativa para
dar à fábula uma base de fato. Nesse caso, o fato é o argumento,
as notações avisam ao leitor que, em sua rede, ele está diante de
uma lenda verdadeira, originária da pesquisa. Além disso, há,
antes da narrativa, um "Prólogo" e um "Argumento Histórico",
depois uma "Carta" e ainda um "Pós-Escrito", colocado na segunda
edição. É um excesso de informações, ou melhor, uma avalanche
de defesas e ataques diante das posições contrárias. Cercando
Iracema, e na sua própria constituição narrativa, há vários indícios
de um longo trabalho de investigação sobre o Brasil no tempo
colonial. ${ }^{27}$

Alencar chegava a questionar até mesmo o método de investigação dos historiadores de seu tempo. No mesmo "argumento histórico" de Iracema, citado por Régis Lopes, o romancista ressaltava a importância da tradição oral enquanto fonte para a história, numa época em que o "fato" deveria ser coletado em documentos escritos, quase sempre vinculados à história política. Pode-se observar ainda um dado intrigante na progressão histórica dos romances indianistas: de O Guarani (1857), passando por Iracema (1865), até Ubirajara (1874), há uma

${ }^{26}$ CANDIDO, Antonio. O romantismo no Brasil. São Paulo: Humanitas, 2004, p. 45.

27 RAMOS, Francisco Régis Lopes. José de Alencar: entre o romance e a história. In: Projeto História, no 43, p. 330, dez., 2011. 
regressão cronológica. Além de ser um autor "best-seller"28 até os dias de hoje, Alencar foi "bem sucedido" também em sua versão para o passado cearense. Seu

argumento histórico alimentou as querelas que chegaram ao séc. XX. Pero Coelho e Soares Moreno transformaram-se em cadeiras cativas na escrita da História do Ceará. Passaram a sintetizar as dificuldades da colonização e se tornaram heróis cearenses, apesar da origem lusitana (...). Refiro-me especificamente à perenidade no âmbito das tentativas de síntese explicativa da História do Ceará, isto é, no âmbito de procedimentos que se legitimam como necessários e adequados para a consolidação de recontes do tempo e do espaço. ${ }^{29}$

Há uma reflexão sistemática nos textos de Alencar sobre um projeto de nacionalidade constituída pela literatura. ${ }^{30}$ Antonio Edmilson Rodrigues afirma que, com o tempo, Alencar se tornou um poeta armado que usou a letra como modo de conhecer e guerrear. ${ }^{31}$

Outro episódio que demonstra bem o espírito combatente do romancista cearense, sempre disposto a travar o debate de ideias em torno das questões cruciais de sua época, é sua famosa querela com Joaquim Nabuco, em 1875, nas páginas do O Globo, a respeito da escravidão e da cultura africana no Brasil. Nabuco dirigiu sua crítica ao deputado do Império que, em seu exercício parlamentar, era favorável à manutenção da escravidão, ao mesmo tempo em que tratava as personagens negras de maneira sentimental em peças como "O Jesuíta" e "O demônio familiar". Nabuco, cosmopolita, atacava o teatro de Alencar como inexpressivo e motivo de vergonha nacional por seu enfoque realista na condição do negro. Sua literatura "indianista" também era rejeitada por aquele que defendia a arte como expressão idealizada da sociedade branca.

Sob o pseudônimo de Erasmo, o romântico escreveu uma série de cartas (1865) avaliando a escravidão como um "fato social necessário", que deveria ser anulado gradualmente a fim de evitar que a agricultura fosse ameaçada e gerasse instabilidade política

\footnotetext{
${ }^{28}$ A imensa vendagem da obra do escritor cearense está, obviamente, ligada a seu interesse em cativar o leitor e ganhá-lo para a literatura, algo associado ao próprio caráter da literatura romântica. Segundo Dante Moreira Leite, em O caráter nacional brasileiro (2002), "embora fosse expressão individualista, indiferente à acolhida do público, a literatura romântica esteve voltada para este, ainda quando ostensivamente não o procurava - o que acontecia com os autores nacionalistas. Por isso, a literatura romântica tende a ser uma literatura fácil, ao alcance de grande número de leitores, quando não ia mais longe para cativar o público feminino, cuja educação era ainda muito elementar". (p.218) Em Como e porque sou romancista (1873) Alencar conta sua experiência como leitor de estórias para sua mãe, tia e amigas, observando as reações do "público" ao acompanhar as situações e personagens conforme a leitura avançava, algo que o marcou bastante em sua habilidade de tecer narrativas envolventes.

29 RAMOS, Francisco Régis Lopes. Fundadores e fundamentos: José de Alencar e a escrita sobre o passado cearense. In: Anais do Museu Histórico Nacional. Rio de Janeiro, 2009, p. 91.

30 "Na América Latina a literatura foi freqüentemente uma atividade devoradora. Quero dizer que durante a formação nacional dos nossos países quase tudo devia passar por ela, e por isso ela foi uma espécie de veículo que parecia dar legitimidade ao conhecimento da realidade local. O orador, o escritor de estilo sugestivo, o visionário inspirado entram na fórmula do estudioso e do analista, de tal forma que sem literatura os seus trabalhos pareciam menos capazes de convencer." CÂNDIDO, Antonio. Literatura, espelho da América?, s/d.

31 Ver: RODRIGUES, Antonio Edmilson Martins. José de Alencar - o poeta armado do século XIX. Rio de Janeiro: FGV, 2001.
} 
do Império. A ironia cáustica, o humor ferino e a eloquência de sua fala e estilo, mais uma vez se fazem presente na polêmica.

Apesar do empenho em que anda o folhetinista de molestar-me com seus artigos e dos empertigamentos da vaidade mal disciplinada, eu não posso tomar a sério esses rancores infantis e nitrir ressentimentos contra quem me está divertindo (...). o Sr. Nabuco, tão moço ainda, já conta em sua vida, nada menos de dois suicídios literários. (...) A andorinha que fez seu ninho entre os frisos de uma coluna do Partenon, entende porventura de arte? (...) A escravidão é um fato de que todos nós brasileiros assumimos a responsabilidade, pois somos cúmplices nele como cidadãos do Império. Nenhum filho desta terra, por mais adiantadas que sejam suas ideias, tem o direito de eximir-se à solidariedade nacional, atirando ao nome da pátria, como um estigma, os erros comuns (...). O folhetinista nasceu como a geração coeva em um país de escravos, no seio de uma respeitável e ilustre família servida por escravos. Esses lábios purpurinos, que já não podem sem náuseas pronunciar a palavra moleque, talvez sugassem o leite de uma escrava, como aconteceu, não a mim, porém a muitos outros que não lhe cedem no respeito à dignidade humana. ${ }^{32}$

Nabuco também atacou Alencar por seus romances "indianistas" (O Guarani, Iracema e Ubirajara) como "falsa literatura tupi", imitadores de Cooper e Chateaubriand, desconhecendo a realidade dos selvagens brasileiros. Segundo Roberto Ventura, ${ }^{33}$ a posição de Nabuco exige a exclusão do escravo e do indígena da vida cultural e social, eliminando-o não apenas pelo fim do cativeiro, mas também como tema literário. Ainda em relação à querela, Roberto Schwarz foi por deveras incisivo ao nos alertar que "Nabuco põe o dedo em fraquezas reais, mas para escondê-las; Alencar pelo contrário incide nelas tenazmente, guiado pelo senso da realidade, que o leva a sentir, precisamente aí, o assunto novo e o elemento brasileiro". ${ }^{34}$

Em vários textos, Alencar parece escrever para um público que ainda não existia, para o futuro. Sabia que estava construindo a nação, e que não havia outra maneira de tornar esta nação como algo existente a não ser produzindo um simbolismo forte, e isso, em seus escritos, é um projeto deliberado. Seus textos políticos são de uma lucidez e de um conhecimento de tudo que se escrevia em matéria de ciência política e de Teoria do Estado, Parlamento, etc. Nesse sentido, seus pronunciamentos registrados na polêmica em torno da Confederação dos Tamoios (1856), até o prefácio de Sonhos d'Ouro, de 1872, e o ensaio Como e porque sou romancista (1873), constituem, segundo Coutinho, "uma contribuição definitiva à fixação e compreensão do problema, sem o qual não seria talvez possível a doutrina exposta no ensaio

\footnotetext{
32 COUTINHO, Afrânio (org.). Caminhos do pensamento crítico. Vol 1. RJ: Pallas, 1980, p. 232,233 e 235.

33 VENTURA, Roberto. Estilo Tropical. São Paulo: Companhia das Letras, 1991.

34 SCHWARZ, Roberto. Ao vencedor as Batatas: forma literária e processo social nos inícios do romance brasileiro. São Paulo: Duas Cidades, 1981, p. 32.
} 
de Machado de Assis, 'Instinto de Nacionalidade', o qual encerra a conceituação e formulação definitivas". 35

O balanço da obra alencarina aponta no sentido de uma dupla personalidade conflitante: o político e o poeta ficcional. Para o sociólogo Eduardo Diatahy, trata-se de uma dicotomia fraca e sintética, pois Alencar soube unir com equilíbrio, ainda que sob alguma tensão, essas duas dimensões. ${ }^{36}$ Em 1861, Alencar saiu do Ceará com um diploma de Deputado Geral e com o manuscrito de Iracema, ou seja, em plena campanha política ele escrevia sua obra (em 1861), publicando-a em 1865. Toda a sua obra tem uma deliberação muito prática: romances históricos (grandes temas e tratados ficcionalmente), romances regionais (criando tipos nacionais), faz teatro com proficiência e cria um romance urbano, Senhora (1875).

Desse modo, podemos observar a estreita imbricação entre romantismo e nacionalismo, por vezes tornando-se a mesma coisa, na medida em que ser nacionalista consistia em escrever sobre assuntos locais. Encontramos no romantismo a gênese de nossa crítica nacionalista, que se estenderá por todo o oitocentos, avaliando o escritor e sua obra a partir do "critério de nacionalidade", ou seja, na medida em que sua literatura contribuísse para o engrandecimento da nação através da descrição de seus temas e costumes, enfatizando, sobretudo, suas qualidades originais.

O problema está em que, no quadro do projeto nacional inaugurado pelo romantismo, a originalidade, a novidade e a diferença da literatura brasileira se entendem fundadas na originalidade, na novidade e na diferença do próprio Brasil: será preciso, então, acreditar que o Brasil não resiste à literatura e que esta, por sua vez, não resiste ao Brasil. ${ }^{37}$

A história literária brasileira traz, desde os primeiros esboços no romantismo, a definição de uma entidade abstrata corporificada nas obras, criações individuais que refletiriam um "caráter" ou "espírito" coletivo: o ser nacional. Busca-se uma essência, situada em uma teleologia inscrita na ordem natural das coisas (...) evolução linear e contínua que traria a encarnação progressiva e metafísica do ser nacional, das origens até sua plena realização. ${ }^{38}$

Quando um bando de ideias novas surgiu (Positivismo, Naturalismo, Evolucionismo, Liberalismo, Republicanismo), Alencar já estava perto de sua morte, com apenas 48 anos. Machado de Assis partiria de seu legado para, com seu gênio perspicaz e criativo, mostrar a sociedade brasileira em suas mais variadas facetas e contradições, aprofundando a reflexão

\footnotetext{
35 COUTINHO, Afrânio. A tradição afortunada (o espírito de nacionalidade na crítica brasileira). São Paulo: José Olympio, 1968, p. 102.

36 MENEZES, Eduardo Diatahy B de. Alencar e seu projeto literário de construção nacional. In: Tensões Mundiais, v. 9, n.16, p. 176-195, 2013.

37 BAPTISTA, Abel Barros. A formação do nome. Duas interrogações sobre Machado de Assis. Campinas: Ed. Unicamp, 2003, p. 29.

38 VENTURA, Roberto. Estilo Tropical. São Paulo: Companhia das Letras, 1991, p. 166.
} 
sobre os problemas patentes de um país atravessado por contradições. Caberia a ele, com Instinto de Nacionalidade (1873), a missão de expurgar o "fardo Brasil" do escritor brasileiro. Em vários momentos, a querela entre os "homens de letras" e os "homens de ciência" será um desdobramento inevitável desse desafio.

É aqui que tem importante lugar a polêmica travada entre Sílvio Romero e Machado de Assis. Fruto da reação de Romero a um artigo acerca da Nova Geração, publicado em 1879 na Revista Brasileira, a discussão explicita as diferentes formas de pensar o Brasil que naquele momento se confrontavam. Machado atacava o "criticismo" dos novos poetas, entre eles Romero, que lançaram um programa de fundação da moderna poesia a partir dos princípios gerais da ciência. Apontou ainda a falta de estilo que é uma grande lacuna nos escritos do Sr. Sílvio Romero. Além disso, considerou exacerbada a importância atribuída aos poetas pernambucanos, como Tobias Barreto e Castro Alves. Machado dizia que "pertenceu o Sr. Romero ao movimento hugoísta, iniciado no Norte e propagado ao Sul, há de haver alguns anos; movimento a que este escritor atribui uma importância infinitamente superior à realidade." E continuava: "Entretanto, não se Ihe distinguem os versos pelos característicos da escola, se escola the pudéssemos chamar; pertenceu a ela antes pela pessoa do que pelo estilo".

Nada mais ultrajante para o polemista Sílvio Romero do que ser "atacado" justamente naquilo que acreditava ter sumo valor para sua reputação de crítico literário: a Escola do Recife. Em sua postura permanentemente ofensiva, denunciou a falta de valor da obra machadiana, uma mescla de romantismo com resquícios de classicismo. Tal "romantismo tardio" machadiano estaria em descompasso, atrasado mesmo, com as tendências contemporâneas e, portanto, não teria lugar nos elos da cadeia da vida intelectual brasileira. Retrucou as críticas dirigidas contra o grupo do Recife, "(...) é um dos pontos de história espiritual brasileira em que sou intransigente: o valor do movimento iniciado no Recife desde 1862." ${ }^{39}$, e demarcou, ironicamente, as frentes entrincheiradas de batalha "Era um progresso irrecusavelmente no fundo e na forma, tinha apenas um defeito: não era coisa nascida na freguesia da Candelária, a ser papagueada pelos blasés da rua do Ouvidor." 40

Em sua obra Machado de Assis. Estudo comparativo de literatura brasileira (1897), de onde tiramos o excerto anterior, Romero adota o critério evolucionista e etnográfico na análise da literatura, focando o "povo" ao invés do "indivíduo". Desse modo, a literatura se relaciona à sociedade por intermédio do indivíduo, que deve ser o "espírito representativo" de sua época. Para Roberto Ventura, que estudou bem as polêmicas literárias no Brasil oitocentista, o critério evolucionista se torna um rolo compressor que reduz e nivela a literatura a uma série sucessiva de estilos e escolas em que os escritores são avaliados de acordo com o grau de correspondência com as tendências eleitas pelo crítico.

Romero criticou ainda a ironia, o humor e o ceticismo, presentes fortemente na prosa machadiana, como imitação forçada de autores externos, sobretudo ingleses como Laurence

39 CANDIDO, Antônio. Brigada Ligeira e outros escritos. São Paulo: Unesp, 1992, p. 104.

${ }^{40}$ Id. Ibid., p. 74 e 75. 
Sterne $^{41}$, que inspirou a forma digressiva e a quebra cronológica de Memórias póstumas de Brás Cubas. Desse modo, para a crítica etnográfica de Romero, o escritor fluminense distorcia a realidade brasileira em sua obra, cuja miopia provocada pela sua apropriação afetada de autores europeus o desprovia do "selo nacionalista", não propriamente no objeto de sua obra, mas no seu espírito de escritor.

Nesse sentido, uma das tendências mais importantes para Romero será o critério de nacionalidade. Falamos rapidamente, quando tratamos do período das ideias românticas, acerca da formulação inicial da "Lei Brasil", que determinava a importância da obra de um escritor pelo que ela trazia de contribuição para o progresso da Nação. Aqui, a crítica nacionalista se faz vigorosa, suscitando um debate envolvente, no qual tomou parte os três maiores nomes da crítica oitocentista: Sílvio Romero, defensor intransigente do critério de nacionalidade; José Veríssimo, o mais esteticista de todos; e Araripe Jr., com sua peculiar teoria da obnubilação ${ }^{42}$ do escritor.

Segundo Roque Spencer, é com a crise de renovação assinalada pela geração de 1870 que chegou o momento de tomar partido, não sendo mais possível a coexistência de diferentes concepções de vida (católicos que não precisavam suas ideias; conservadores no partido liberal e liberais no partido conservador; a escolástica e o espiritualismo eclético; aceite da religião do estado e suas consequências; omissão de enfrentamento ao problema da escravidão). Nesse sentido, o primeiro impacto gerado pelas novas ideias seria o de impedir a acomodação anterior e obrigar a tomada de posições, forçando os homens a tomarem decisões seguras de seu caráter. É então que os tipos se definem. Três mentalidades se configuravam frente às novas ideias: católico-conservadora, liberais e cientificistas. A geração de 70 faria diagnósticos de problemas amplos e variados, sem, contudo, elaborar projetos.

Essa transformação no horizonte mental da época, provocada pela agitação do bando de ideias novas, está intimamente imbricada às transformações sócio-político-econômicas que atravessavam o Brasil, "sobretudo a verdadeira revolução que se opera na distribuição de suas atividades produtivas." 43 Citando Caio Prado Jr., Cruz Costa constata que tal revolução se completa na segunda metade do século com:

a decadência das lavouras tradicionais do Brasil - cana-de-açúcar, tabaco, algodão - e o desenvolvimento paralelo e considerável da produção de um gênero até então de pequena importância: o café, que acabará por figurar quase isolado na balança econômica

\footnotetext{
${ }^{41} \mathrm{Em}$ A vida e as opiniões do cavalheiro Tristram Shandy (1759), Laurence Sterne desnudava a estrutura própria do romance. Para o formalista russo Víctor Chklóvski, por isso mesmo ela era a obra romanesca mais típica da literatura universal, contrariando a visão que se sustentava na época que a enxergava como um caso de exceção e de extravagância. (Ver: CAMPOS, Haroldo de. Serafim: um grande NãoLivro. In: Obras completas de Oswald de Andrade. Rio de Janeiro: Civilização Brasileira, 1978.)

42 Por princípio da "obnubilação", busca-se explicar o fenômeno da diferenciação. Segundo Araripe Jr., o gradual afastamento dos colonos da costa e pequenos povoados, adentrando o interior, fez os homens regredir para uma condição primitiva, deixando o estado de civilizados para se adaptar ao meio e se habilitar às lutas. Esse processo causaria tantas transformações nos indivíduos que um novo homem seria criado. Desse modo, não há como dar continuidade ao homem europeu nas terras descobertas.

43 CRUZ COSTA, João. Contribuição à história da ideias no Brasil. RJ: Civilização Brasileira, 1967, p. 98.
} 
brasileira (...) já na primeira metade do século XIX o centro-sul irá progressivamente tomando a dianteira das atividades econômicas do País. E na segunda chega-se a uma inversão completa de posições: o Norte estacionário senão decadente; o Sul em primeiro lugar e em pleno florescimento. ${ }^{44}$

O ano de 1870 marca, assim, a efervescência de um turbilhão de novas ideias que atravessava a vida intelectual brasileira. Positivismo, naturalismo, evolucionismo, todas as modalidades do pensamento europeu serão incorporadas e exprimidas pelo pensamento nacional, norteando sua trajetória e promovendo um notável progresso no espírito crítico.

A produção "intelectual" da geração de 1870 pode ser lida como expressão da crítica dos grupos sociais letrados às instituições, às práticas e aos valores do status quo imperial. Suas obras não são idênticas, mas são estruturalmente assemelhadas. Tanto em sentido quanto em organização e estilo. Vistas em conjunto, salta aos olhos um substrato comum. As tópicas da geração 1870 são um espelho invertido do mundo saquarema: o anticlericalismo, 0 antiindianismo romântico, o antiliberalismo imperial. A construção dessa tríade negativa é produto da assimilação da política científica. ${ }^{45}$

A guisa de conclusão: o "rasante" que lançamos aqui sobre a convulsão de ideias que se instalou no Brasil oitocentista nos permite antever o surgimento de uma doença que atingirá profundamente uma das mentes mais brilhantes que a vida espiritual brasileira assistirá no século XX: cinquenta anos depois do bando de ideias novas, Mário de Andrade sofrerá de brasilite. ${ }^{46}$

Antônio Sérgio Pontes Aguiar: Doutorando pelo Programa de Pós-Graduação em Literatura, Cultura e Contemporaneidade da PUC-Rio. Graduado em Historia pela Universidade Federal do Ceará (UFC) e Mestre em Historia pela PUC-RJ com pesquisa sobre folclore e cultura popular no Ceará do século XIX. Atualmente estuda literatura de testemunho na obra de Sebald.

Ruben Maciel Franklin: Doutor em História Social pela Universidade Federal Fluminense (UFF) e professor adjunto A da Universidade da Integração Internacional da Lusofonia Afrobrasileira (UNILAB-CE). Graduado em Historia pela Universidade Federal do Ceará (UFC) e Mestre em Historia Social pela mesma instituição com pesquisas relacionadas à imigração estrangeira. No doutorado estudou os intelectuais de esquerda na New Left Review após o colapso do comunismo.

\footnotetext{
${ }^{44}$ Idem.

45 ALONSO, Angela. Ideias em movimento. SP: Paz e Terra, 2002, p. 178.

${ }^{46}$ Aqui, encerramos fazendo referência ao poema "Grafito para Mário de Andrade", de Murilo Mendes.
} 